\title{
ARTHRODENDRON MAGURICUM N. SP., A NEW LARGER AGGLUTINATED FORAMINIFER FROM THE EOCENE MAGURA FLYSCH OF THE POLISH CARPATHIANS AND ITS RELATIONSHIP TO KOMOKIACEANS AND TRACE FOSSILS
}

\author{
MICHAEL A. KAMINSKI ${ }^{1,2}$ ALFRED UCHMAN,${ }^{3}$ AND ANDREW K. RINDSBERG ${ }^{4}$ \\ ${ }^{1}$ Department of Earth Sciences, University College London, Gower Street, London, WCIE 6BT, UK, <m.kaminski@ucl.ac.uk>; currently ${ }^{2}$ Earth \\ Sciences Department, King Fahd University of Petroleum \& Minerals, Dhahran, 31261, Saudi Arabia, <kaminski@kfupm.edu.sa>; ${ }^{3}$ Institute of \\ Geological Sciences, Jagiellonian University, Oleandry 2a, 30-063, Kraków, Poland, <alfred.uchman@uj.edu.pl>; and ${ }^{4}$ Department of Biological \& \\ Environmental Sciences, Station 7, University of West Alabama, Livingston, AL 35470, USA, <arindsberg@uwa.edu>
}

\begin{abstract}
Arthrodendron maguricum n. sp. is described from deep-sea flysch of the lower Eocene Życzanów Conglomerate Member of the Szczawnica Formation (Magura Unit) in the Polish Carpathians. Arthrodendron maguricum is a larger agglutinated foraminifer showing regular, tubular chambers that may branch dichotomously. Its wall is tripartite and composed of an outer organic-rich layer, a main agglutinated layer, and an internal organicrich layer. The organism evidently lived as epibenthos on the muddy sea floor. Because of their branching morphology and comparatively large dimensions, larger agglutinated foraminifera of the genus Arthrodendron have previously been confused with algae and trace fossils. Care should be taken in such cases to resolve the agglutinated wall and chambers of this deep-water agglutinated foraminifer. Arthrodendron maguricum displays superficial similarities to some modern komokiaceans, especially to Septuma. Further investigations are needed for clarification of their affinities and possible taxonomic consequences.
\end{abstract}

\section{INTRODUCTION}

$\mathrm{F}$ OR OVER $150 \mathrm{yr}$, representatives of the genus Arthrodendron Ulrich, 1904 have been described under a variety of names, as either marine plants or trace fossils from deepmarine clastic sediments (Kaminski et al., 2008). In Europe, these fossils have been recognized as belonging to the agglutinated foraminifera since the 1960s and have been widely referred to the genera "Aschemonella Brady, 1879" or "Aschemocella Vialov, 1966." These larger agglutinated foraminifera have been found in Upper Cretaceous and Paleogene flysch sediments from the northern Alps in Austria and Switzerland (Unger, 1841; Heer, 1877; Fuchs, 1894), and the whole of the Carpathian arc in Poland, Slovakia, the Ukraine, and Romania (Świdziński, 1934; Geroch, 1960; Neagu, 1964; Vialov, 1966; Kaminski and Geroch, 1993; Kaminski and Gradstein, 2005; Kaminski et al., 2008), as well as Alaska (Ulrich, 1904).

Specimens of Arthrodendron recovered by normal micropaleontological methods are usually fragmentary, and such specimens are often not assigned to any particular species or are simply regarded as belonging to the type species of the genus Aschemocella (Aschemonella carpathica Neagu, 1964). Fortunately, occasional specimens are recovered from turbidite sandstone layers in the Carpathian flysch deposits that can provide unique insight into the morphology and habitat of the whole organism. This paper documents a single well-preserved specimen of a new species of Arthrodendron from the lower Eocene Magura flysch of the Polish Carpathians, which we here describe as Arthrodendron maguricum n. sp.

Geological setting.-The Magura Nappe is the southernmost large tectonic unit of the Polish Outer Carpathians. Deposits of this unit accumulated from the mid-Cretaceous to the early Oligocene in the long-lived, flysch-dominated Magura Basin (e.g., Oszczypko, 1992). The studied section lies in the southernmost facies zone of the Magura Basin, i.e., in the Krynica Zone. The section, 70 m thick, is exposed along the terminal part of Życzanów stream, a tributary of the Poprad River (Fig. 1). This is the type section of the Życzanów Conglomerate Member of the Szczawnica Formation (Birkenmajer and Oszczypko, 1989; Oszczypko et al., 1990). The section is composed of two packages dominated by thick-bedded conglomerates and sandstones separated by a package of thin- to medium-bedded siliciclastic flysch (Fig. 2). The lower package is interpreted as a channel fill, the middle "normal" flysch package as "one of non-channelized fan facies or basin plain deposits," and the upper package as a "depositional lobe followed by channel incision and filling" (Oszczypko and Porebski, 1985, 1986). Within the middle package, the cited authors indicated that the "local divergence of flow directions by as much as $90^{\circ}$ is suggestive of overbank spilling of flow" (Oszczypko and Porębski, 1985), which is rather typical of interchannel areas. The age of the Życzanów Conglomerate Member has been determined as early Eocene based on calcareous nannoplankton (Oszczypko et al., 1990) and agglutinated benthic foraminifera examined in this study. The accompanying assemblage of smaller agglutinated benthic foraminifera points to deposition in a lower bathyal environment beneath the CCD.

The described larger agglutinated foraminifer derives from the middle part of the section (Fig. 2) from the base of a 10$\mathrm{cm}$ thick, fine-grained sandstone bed covered by a $3.5-\mathrm{cm}$ thick layer of grey mudstone. The sandstone bed displays parallel lamination ( $\mathrm{Tb}$ Bouma interval) in its lower part and cross-bedded lamination (Tc Bouma interval) in its upper part.

\section{SYSTEMATIC PALEONTOLOGY}

In this study we use the agglutinated foraminiferal classification of Kaminski (2004). The genus Arthrodendron and its synonyms and type species have recently been transferred to the Foraminifera and revised by Kaminski et al. (2008), who regarded the genus Aschemocella Vialov, 1966 as a junior synonym of Arthrodendron Ulrich, 1904. 


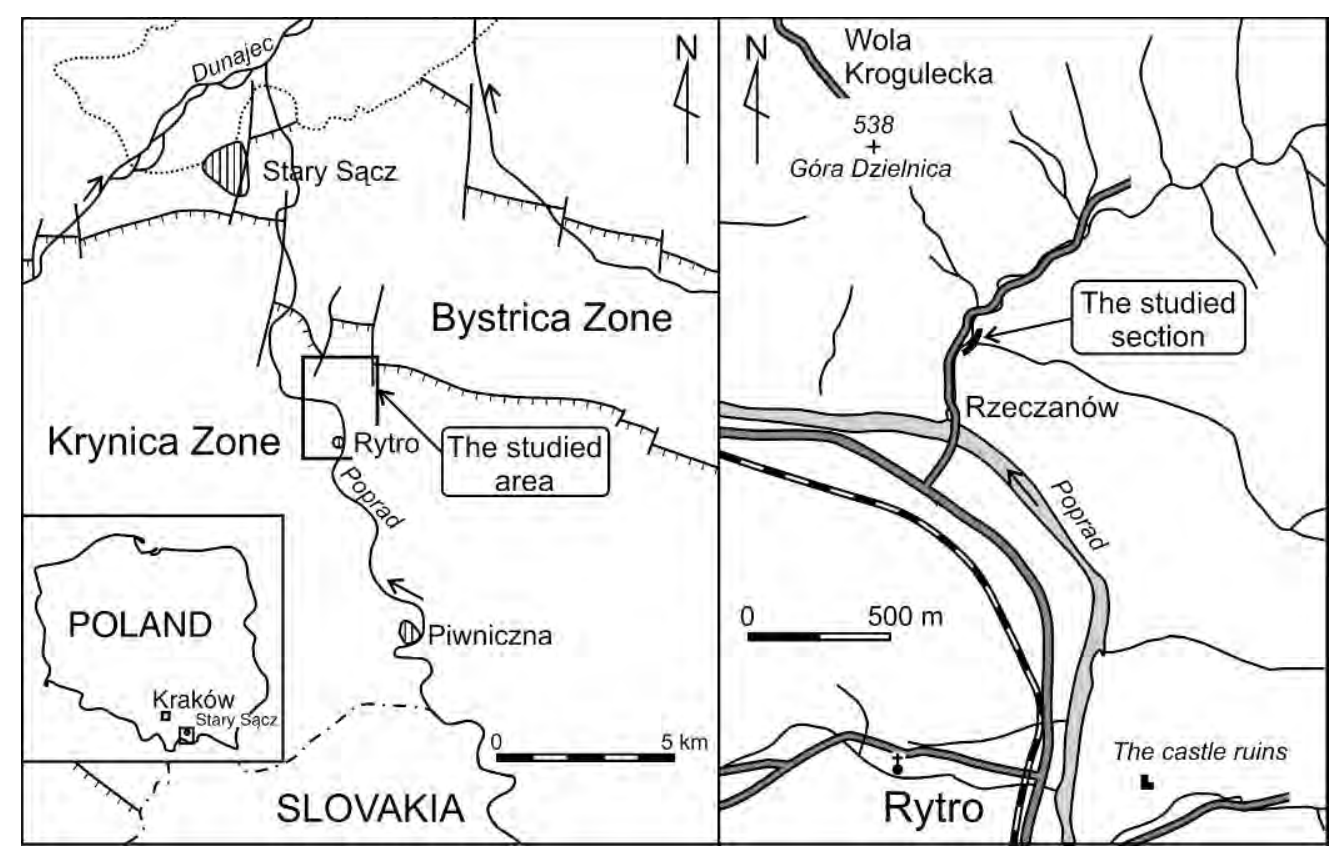

FIGURE 1-Map showing the location of the Życzanów stream section.

Class Foraminiferea d'Orbigny, 1826

Subclass TeXTUlariIA Mikhalevich, 1980

Order LiTUOLIDA Lankester, 1885

Suborder HoRmosinina Mikhalevich, 1980

Superfamily HormosinACEA Haeckel, 1894

Family AsCHEMOCELLIDAE Vialov, 1966

Genus ARTHRODENDRON Ulrich, 1904

Diagnosis.-Branched chains of large chambers with an imperforate agglutinated wall that lacks biogenic barite crystals (Kaminski et al., 2008).

Remarks.-Arthrodendron [=Aschemocella Vialov, 1966] differs from other hormosinaceans in its large dimensions and in having a branching septate test. The test consists of many chambers in a meandering series that may branch from a central area. These tubular chambers may branch further. The various species of Arthrodendron are distinguished by the predominant chamber shape.

\section{ARTHRODENDRON MAGURICUM n. sp.}

Figures $3.1-3.2 ; 4.1-4.2$

Diagnosis.-A large Arthrodendron with sinuous tubular chambers that branch mainly from the outbows of curves, generally only for a short distance outward from a septum.

Description.-Test large for the genus, dichotomously branched, composed of large tubular chambers constructed of fine-grained material, compacted convex-upward along shale-sandstone interface. The test is flattened and was probably originally tubular. The visible part of the test is subparallel to bedding, partly concealed within the sandstone; the central area or proloculus is not seen. Chambers are embracing, constricted slightly at the septa. Chambers are of nearly constant width throughout, ranging from a minimum of $1.2 \mathrm{~mm}$ at the septa to a maximum of $2.6 \mathrm{~mm}$ across the widest chamber, with a maximum length of about $7 \mathrm{~mm}$. Chambers are 3-4 times as long as wide, separated by externally raised septa, and are bordered by a raised rim owing to compression of the chamber. Branches are sparse, positioned a short distance outward from a septum, mainly at outbows of curves, resulting in superficially symmetrical dichotomy. Tips of branches are bluntly rounded, smooth in most cases; possibly perforate with two or three small apertural openings on raised mound-like collars in some cases. Radius of the specimen is 50 to $70 \mathrm{~mm}$. The test wall is thick and distinctly trilamellar (Fig. 4). The external organicrich layer is 50 to $100 \mu \mathrm{m}$ thick. It contains small quartz grains up to $30 \mu \mathrm{m}$ in diameter dispersed among dark organic matter. Locally, the layer displays a discontinuous external zone, about $10-20 \mu \mathrm{m}$ thick, which contains more organic matter than in the main part of the layer. The layer is sharply bound with the main agglutinated layer, which is $100-150 \mu \mathrm{m}$ thick, contains quartz grains $10-60 \mu \mathrm{m}$ in diameter, and much less organic matter than in the external organic-rich layer. The internal organic-rich layer is up to $50 \mu \mathrm{m}$ thick; it contains dispersed quartz grains up to $10 \mu \mathrm{m}$ in diameter floating in a dark organic matrix. Its boundary with the main agglutinated wall is diffuse. According to the microprobe analysis, there is no evidence of barite.

Types.-Deposited in the Geological Museum, Jagiellonian University, Kraków. The holotype is listed under catalogue nr. INGUJ-175P1a, b (two complementary slabs); a paratype is catalogued as INGUJ-175P2. Type locality: Życzanów stream, a tributary of the Poprad River, between Rytro and Stary Sącz, Poland (Figs. 1, 2).

Etymology.-From the Magura Unit of the Carpathian Flysch.

Occurrence.-Lower Eocene Życzanów Conglomerate Member of the Magura Unit, Polish Carpathians.

Discussion.-The holotype specimen is likely to be incomplete, as it is located near the edge of the sandstone slab. The specimen gives the impression of branching away from one corner of the slab, but no proloculus or center of organization is visible.

The visible part of the test occurs at a shale-sandstone interface, the shale having weathered away, but the wellorganized branching was apparently undisturbed, indicating that the foraminifer is in life position. Part of the test is concealed within the sandstone, which is a turbidite layer $13 \mathrm{~cm}$ thick. The foraminifer thus probably grew at or close to 


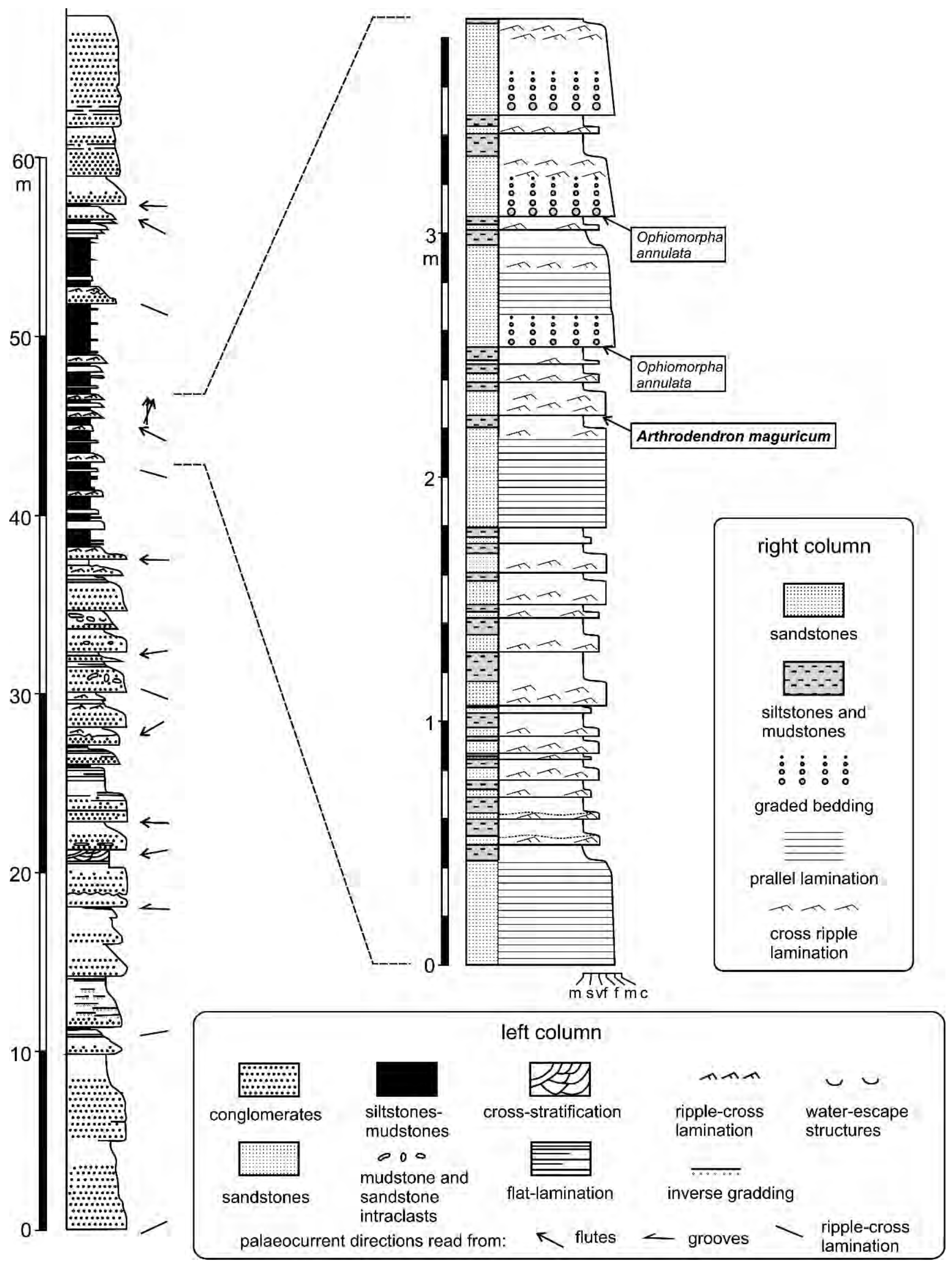

FIGURE 2-Stratigraphic column of the studied section with indication of the bed bearing Arthrodendron maguricum sp. n. The left column is redrawn from Oszczypko and Porębski (1986). 


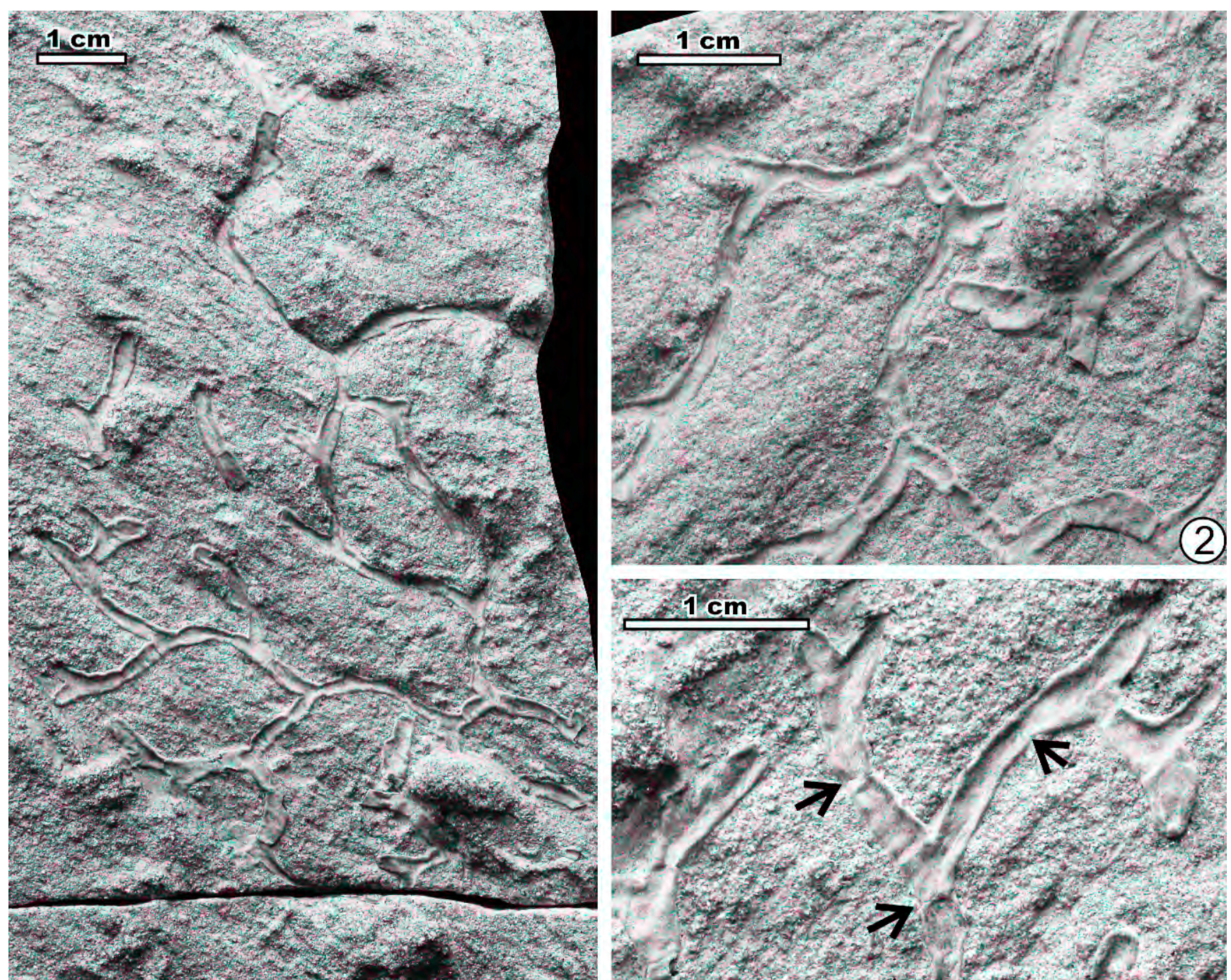

FIGURE 3-Holotype of Arthrodendron maguricum n. sp. (catalogue nr. INGUJ-175P1a, b), attached to the underside of a turbiditic sandstone layer, Życzanów stream section, lower Eocene Życzanów Conglomerate, Magura Unit of the Polish Carpathians. 1, general view; 2, 3, details of view 1. Arrows in 3 point to the septa.

the sediment-water interface before the turbidity current deposited the sand, but disturbance by the turbidity current was minimal in this case. Another specimen was fragmented, suggesting that the test was relatively tough during life. The convex-upward compaction of the test is a striking feature, requiring that the tube was pressed upward against the sand layer while being deflated. This may have occurred as clay was compacted and deformed upward beneath the sand.

This species differs from previously known species of Arthrodendron in having regular branching morphology and in possessing overlapping tubular chambers that have only minor constrictions at the sutures. The type species, Arthrodendron diffusum, which Ulrich (1904) described from the Upper Cretaceous flysch of "Kadiak" (now Kodiak) Island,
Alaska, differs in having more clearly defined, oval chambers. Kaminski et al. (2008) regard the Carpathian species Aschemonella carpathica Neagu, 1964 as a junior synonym of A. diffusum. Arthrodendron subnodosiformis (= Hyperammina subnodosiformis Grzybowski, 1898) differs in its smaller dimensions, thinner wall, and more irregular chamber shape (Kaminski and Geroch, 1993).

Associated small agglutinated foraminifers. - Two samples of mudstone underlying (sample Życzanów 1) and overlying (sample Życzanów 2) the Arthrodendron-bearing sandstone bed were examined for small foraminifera. Sample Życzanów 1 contains unidentifiable fragments of Arthrodendron sp., and Arthrodendron grandis (Grzybowski, 1898), as well as Nothia robusta (Grzybowski, 1898), Nothia excelsa (Grzybowski, 


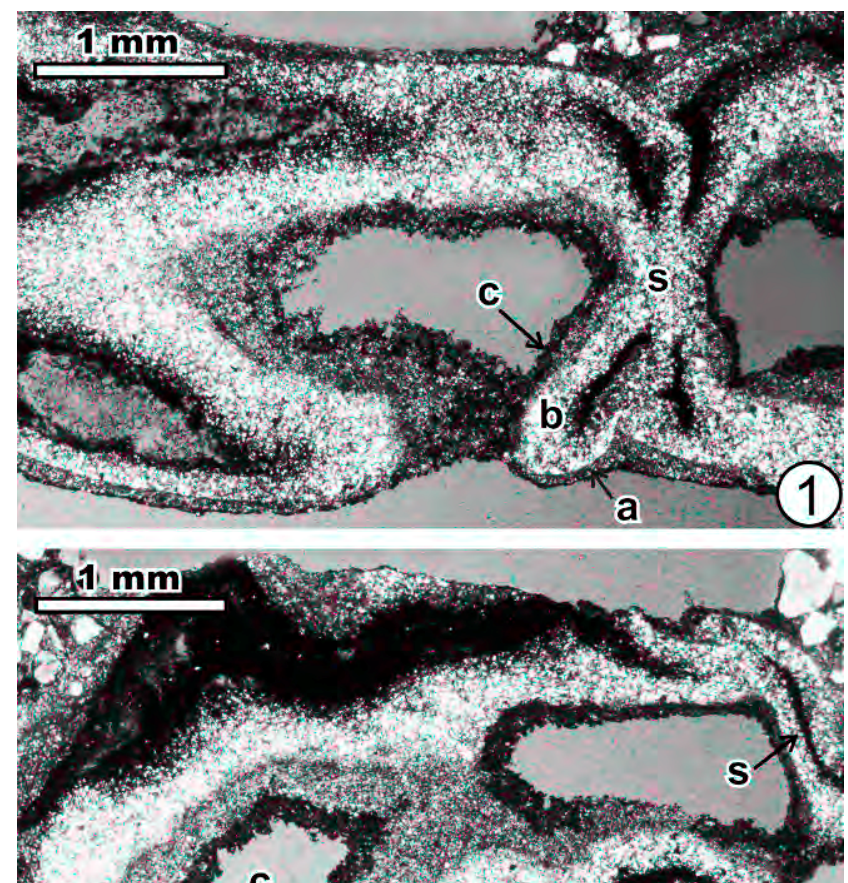

FIGURE 4-Wall structure of a fragment of Arthrodendron maguricum $\mathrm{n}$. sp. in thin section. 1, 2, details of the same folded chamber fragment, which was cut horizontally. Details of the test: a. external organic-rich layer; b. main agglutinated wall layer; c. internal organic-rich layer; s. septum.

1898), Placentammina placenta (Grzybowski, 1898), Paratrochamminoides deflexiformis (Noth, 1912), Saccammina grzybowskii (Schubert, 1902), Ammodiscus tenuissimus Grzybowski (1898), Recurvoides spp., Trochamminoides dubius (Grzybowski, 1901), Trochamminoides proteus (Karrer, 1866), Haplophragmoides cf. walteri (Grzybowski, 1898), Subreophax scalaris (Grzybowski, 1896), Psammosiphonella cylindrica (Glaessner, 1937) and Reophax pilulifer Brady, 1884. Sample Życzanów 2 contains Nothia robusta, Nothia excelsa, Placentammina placenta, Reophax spp., Saccammina grzybowskii, Paratochamminoides deflexiformis, Recurvoides spp., Ammosphaeroidina sp. and Ammodiscus tenuissimus.

Both samples are dominated by tubular agglutinated foraminifera, a feature that is typical of flysch-type assemblages from clastic sequences. Age-diagnostic Paleocene and middle Eocene index species of agglutinated foraminifera are absent, but the dominance of Nothia excelsa suggests an early Eocene age. This species often displays an acme in the middle part of the lower Eocene in the North Atlantic and western Tethys (Kaminski and Gradstein, 2005).

\section{DISCUSSION}

Comparison with living komokiaceans.-Komokiaceans (astrorhizid foraminifera characterized by a flexible test agglutinated from silt and clay particles) were first systematically described thirty years ago by Tendal and Hessler (1977). The organisms are fragile and must be collected and processed by gentle methods such as careful washing of box-cored material. Aside from a brief report of possible komokiaceans from the
Scaglia Rossa of Italy by Kaminski et al. (1989), they have no previously reported fossil record. Tendal and Hessler (1977) elucidated the morphology and ecology of modern komokiaceans. The komokiacean test consists of a system of fine branching tubules of even diameter. Their test wall is agglutinated, flexible, made of argillaceous particles in organic cement covering a thin, laminated inner organic layer. Stercomata (fecal pellets) accumulate within the tubules, and there is no recognizable aperture other than simple perforations in the wall. The komokiaceans often have a bushy or arborescent shape, constructed of widely spaced branching cylindrical tubules that may be of equal diameter throughout or have clublike terminations. They are commonly nonseptate, although a few may have variably spaced septa, forming pseudochambers. The living cytoplasm occupies only part of the test at one time.

Tendal and Hessler (1977) found komokiaceans in samples from the Atlantic, Pacific, and Indian Oceans at water depths ranging from at least $180 \mathrm{~m}$ to $7,298 \mathrm{~m}$. As a whole, they characterize the very oligotrophic areas of the oceanic abyssal plains. One genus described as a komokiacean (Globipelorhiza) has been described from depths as shallow as $60 \mathrm{~m}$ in the Kosterfjord in Sweden (Cedhagen and Mattson, 1991) but its affinity to the superfamily Komokiacea is now thought to be questionable (A. Gooday, personal commun. to MAK, 2008). Their bathymetric range is thus bathyal to hadal.

The modern komokiacean Catena Schröder, Medioli and Scott, 1989 is externally very similar to Arthrodendron and the question of their synonymy requires further investigation. The type species, Catena piriformis Schröder, Medioli and Scott, 1989, is a branched chain of elongate or pyriform chambers that may have an additional aperture produced on a neck, as in Arthrodendron. Because of the presence of internal stercomata, Schröder et al. (1989) placed their new genus in the family Baculellidae Tendal and Hessler, 1977 within the Komokiacea. Whether Catena is a junior synonym of Arthrodendron remains an open question.

Another modern komokiacean, Septuma Tendal and Hessler, 1977, has a bushy arborescent test up to $3 \mathrm{~mm}$ across, with sparse dichotomously branching tubules of nearly constant diameter throughout. The interior of tubules have regularly spaced transverse septa, each with a simple circular foramen, and the terminations of branches are rounded. The wall is flexible but stiff, with a thin inner organic layer and thicker outer layer of agglutinated clay- to silt-sized particles; its surface may appear wrinkled and its color is tan. Septuma differs from our new species of Arthrodendron in its much smaller dimensions and in displaying branching that chiefly occurs near the base. The holotype of the type species, Septuma ocotillo, recently re-illustrated by Gooday et al. (2007), would easily fit inside a single chamber of our new Arthrodendron. The wall of Septuma and other komokiaceans is flexible, thin, and distinctly argillaceous, whereas the wall of Arthrodendron maguricum is thick and composed of wellsorted, silt-sized quartz grains. The septa of Septuma are formed by simple invaginations of the inner organic layer, defining pseudochambers, whereas Arthrodendron maguricum possesses true overlapping chambers. In summary, because it possesses a solid wall and true overlapping chambers (instead of pseudochambers) we retain Arthrodendron within the Hormosinina, but the question of synonymy with forms described as komokiaceans requires further investigation.

Pitfalls of interpretations as algae and trace fossils.-Because of their large size and branched morphology, Arthrodendron and similar foraminifers are easily mistaken for trace fossils, 
and because they occur along with trace fossils, they were often described together even after their nature was established. This pattern of misinterpretation has continued from the nineteenth century, when trace fossils were commonly interpreted as algae (including fucoids) and palaeontologists observing chains of chambers ascribed them to red, green and brown algae. Such is the case with Corallinites halimeda Unger, 1841 from the "Jurassic" of Austria, Hormosira moniliformis Heer, 1877 from the flysch of Freiberg Canton, Switzerland, Halimeda saportae Fuchs, 1894 from the Eocene Greifenstein Sandstone of Kritzendorf, Austria, and Arthrodendron diffusum Ulrich, 1904 from the Upper Cretaceous Kodiak Formation of Alaska. All these specimens are now thought to be larger agglutinated foraminifers belonging to the genus Arthrodendron Ulrich, 1904 (Kaminski et al., 2008).

By the twentieth century, when the burrow nature of "fucoids" and other so-called fossil seaweeds had been established, these large, branched agglutinated foraminifers were still commonly ascribed to trace fossils or considered as closely related problematica. Götzinger and Becker (1932) considered them as "problematische Lebensspuren." Swidziński (1934) described Halysium problematicum as a form of unknown origin, and in the Treatise on Invertebrate Paleontology, Häntzschel (1975) ascribed the latter to "Body Fossils" and synonymized it with Halimeda saportae Fuchs, reservedly with Hormosira moniliformis Heer, and with Arthrodendron Ulrich. Seilacher (1959, fig. 36) considered Halimeda saportae Fuchs as a "Körperliche Gebilde" associated with flysch trace fossils. Kern (1977) described Halysium problematicum Świdziński from the Upper Cretaceous Sieveringer Beds of Austria alongside trace fossils, but indicated that the nature of the fossil remained unknown. More recently, Plička and Thomka (1990) described the foraminifer as a new species of green algae, Halimedaites carpaticus (Upper Cretaceous Łupków Beds of Slovakia). Finally, some species originally described as trace fossils appear to be specimens of Arthrodendron, including Chondrites flexilis from the Upper CretaceousPaleocene Ropianka Beds of the Polish Carpathians illustrated by Książkiewicz (1977, pl. 4, fig. 10) (Uchman, 1998). Crimes et al. (1981, pl. 4, fig. 2) presented a similar foraminifer from the upper Paleocene Gurnigel Flysch of Switzerland as the trace fossil Megagrapton irregulare.

In contrast to true algae, the large branched foraminifera display a test composed of chambers with an agglutinated wall. The chambered test is the main feature separating the foraminifera from trace fossils. Many trace fossils have a constructed wall (e.g., Bromley, 1996) but the conduit (lumen) bounded by the wall is continuous, without strong constrictions, to allow passage of the organism's body. Trace fossils never display a thick organic layer on the wall exterior.

The tests of the larger foraminifera behave as rigid bodies and thus are commonly fragmented by bottom currents and transported. Fragments of Arthrodendron are present in sample Życzanów 1, below the Arthrodendron-bearing sandstone bed. This is scarcely ever the case for soft-bottom trace fossils, which instead display erosion or plastic deformation under like circumstances.

The question arises, why should species of Arthrodendron be preserved while the komokiaceans are not? Taphonomic considerations allow us to speculate. Aside from Arthrodendron's relatively large size, its wall was evidently tough enough to withstand erosion and transport by turbidity currents in some cases. The organism's life position, growing horizontally atop or just below the sediment-water interface, would present minimal resistance to laminar currents compared with the

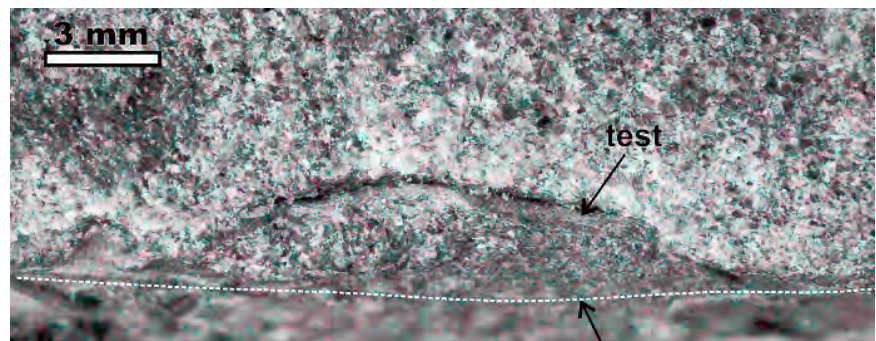

FIGURE 5-Vertical section showing the test of Arthrodendron maguricum n. sp. within the bed.

komokiaceans and other large astrorhizids, many of which have an erect habit. In the case of Arthrodendron maguricum, some of the branches even extended upward for a short distance into the overlying sand that buried it (Fig. 5), but no branches extended anywhere close to the post-turbiditic seafloor. In addition to $10 \mathrm{~cm}$ of sand, $3 \mathrm{~cm}$ of compacted mud must be accounted for atop the holotype. It is unlikely that the foraminifer could live at such a depth within the substrate on only the oxygen available in porewater; oxygen levels within the substrate were evidently low, judging from the presence of pyrite. Further taphonomic understanding awaits the discovery of additional specimens.

\section{CONCLUSIONS}

Arthrodendron maguricum is a new larger agglutinated foraminifer from the Eocene part of the Magura flysch that is distinguished externally by its large size and sinuous tubular chambers that branch mainly from the outbows of curves. The species displays a three-layered chamber wall that is composed of an external organic-rich layer, a main agglutinated layer, and an internal organic-rich layer.

Arthrodendron maguricum was an epibenthic organism living in a prone position on the muddy seafloor. It displays superficial similarities to some modern komokiaceans, especially to Septuma, differing in its layered wall and comparatively large dimensions. Further work may shed light on other species of Arthrodendron and their possible affinity to the living komokiaceans.

\section{ACKNOWLEDGMENTS}

The revision of agglutinated foraminiferal genera is supported by a consortium of petroleum companies and micropaleontological consultancies (BP, Saudi Aramco, Shell, Total, PDVSA, RPS Energy, Fugro Robertson Ltd., Chevron, Petronas). We thank C. Cetean (Polish Academy of Sciences) for reviewing an early version of the manuscript. This is contribution nr. 86 of the Deep-Water Agglutinated Foraminiferal Project. AU was supported by the Jagiellonian University (DS 812 funds), AKR by a University of West Alabama travel grant.

\section{REFERENCES}

Birkenmajer, K. AND N. OsZCZYPKo. 1989. Cretaceous and Paleogene lithostratigraphic units of the Magura Nappe, Krynica Subunit, Carpathians. Annales Societatis Geologorum Poloniae, 59:145-81.

BRADY, H. B. 1879. Notes on some of the Reticularian Rhizopoda of the "Challenger" Expedition. Part I. On new or little known arenaceous types. Quarterly Journal of Microscopical Science, new ser., 19:20-63.

BRADY, H. B. 1884. Report on the foraminifera dredged by H.M.S CHALLENGER during the years 1873-1876. In J. Murray (ed.) Reports of the scientific results of the voyage of the H.M.S. Challenger, Zoology, 9:1-814. 
Bromley, R. G. 1996. Trace Fossils. Biology, Taphonomy and Applications (second edition). Chapman \& Hall, London, $361 \mathrm{p}$.

Cedhagen, T. And S. MatTson. 1991. Globipelorhiza sublittoralis gen. et sp. n., a komokiacean (Protozoa: Foraminiferida) from the Scandanavian sublittoral. Sarsia, 76:209-213.

Crimes, T. P., R. Goldring, P. HoMewood, J. VAN STUIJVEnBerg, AND W. WINKLER. 1981. Trace fossil assemblages of deep-sea fan deposits, Gurnigel and Schlieren flysch (Cretaceous-Eocene). Eclogae Geologicae Helvetiae, 74:953-995.

FuCHS, T. 1894. Über eine fossile Halimeda aus dem eocänen Sandstein von Greifenstein. Sitzungsberichte der Akademie der Wissenschaften, Mathematisch-naturwissenschaftliche Klasse, 103:200-204.

GEROCH, S. 1960. Microfaunal assemblages from the Cretaceous and Paleogene Silesian Unit in the Beskid Sląski Mts. (western Carpathians). Biuletyn Instytutu Geologicznego, 153:7-138. Warszawa

GlaESSNER, M.F. 1937. Studien über Foraminiferen aus der Kreide und dem Tertiär des Kaukasus; 1. Die Foraminiferen der ältesten Tertiärschichten des Nordwest-Kaukas. Problems of Paleontology, 23:349-408. Moscow.

Gooday, A. J., O. E. Kamenskaya, And T. Cedhagen. 2007. New and little-known Komokiacea (foraminifera) from the bathyal and abyssal Weddell Sea and adjacent areas. Zoological Journal of the Linnean Society, 151:219-251.

GöTZINGER, G. AND H. BECKER. 1932. Zur geologischen Gliederung des Wienerwaldflysches (Neue Fossilfunde). Jahrbuch der Geologische Bundesanstalt, 82:343-396. Wien.

GRZYBOWSKI, J. 1896. Otwornice czerwonych iłów z Wadowic. Rozprawy Wydziału Matematyczno-Przyrodniczego, Akademia Umiejętności w Krakowie, serya 2, 30:261-308.

GRZYBOWSKI, J. 1898. Otwornice pokładów naftonosnych okolicy Krosna. Rozprawy Wydziału Matematyczno-Przyrodniczego, Akademia Umiejętności w Krakowie, serya 2, 33:257-305.

GRZYBOWSKI, J. 1901. Otwornice warstw inoceramowych okolicy Gorlic. Rozprawy Wydziału Matematyczno-Przyrodniczego, Akademia Umiejętności w Krakowie, serya 2, 41:219-286.

HäntzSChel, W. 1975. Trace fossils and Problematica. In C. Teichert (ed.), Treatise on Invertebrate Paleontology, Part W., Miscellanea, Supplement 1. Geological Society of America and University of Kansas Press, Lawrence Kansas, 269 p.

HeER, O. 1877. Flora Fossilis Helvetiae. Vorweltliche Flora der Schweiz. J. Wurster \& Co., Zürich, 182 p.

KAMINSKI, M. A. 2004. The Year 2000 classification of agglutinated foraminifera, p. 237-255. In M. Bubik and M. A. Kaminski (eds.), Proceedings of the Sixth International Workshop on Agglutinated Foraminifera. Grzybowski Foundation Special Publication 8.

KAminski, M. A. AND S. Geroch. 1993. A revision of foraminiferal species in the Grzybowski Collection, p. 239-323. In M. A. Kaminski, S Geroch, and D. Kaminski (eds.), The Origins of Applied Micropaleontology: The School of Jozef Grzybowski. Grzybowski Foundation Special Publication 1.

Kaminski, M. A. And F. M. Gradstein. 2005. Cenozoic Cosmopolitan Deep-water Agglutinated Foraminifera. Grzybowski Foundation Special Publication 10, $547 \mathrm{p}$

Kaminski, M. A., F. S. Medioli, AND W. Kuhnt. 1989. Late Cretaceous komoki-like microfossils from Tethyan deep-water limestones: A preliminary report. NATO ASI- $3^{\text {rd }}$ IWAF Conference on the Paleoecology, Biostratigraphy, Paleoceanography, and Taxonomy of Agglutinated Foraminifera. Abstracts and Programme, p. 51.

Kaminski, M. A., A. Uchman, T. Neagu, and C. G. Cetean. 2008. A larger agglutinated foraminifer originally described as a marine plant: The case of Arthrodendron Ulrich, 1904 (Foraminifera), its synonyms and homonyms. Journal of Micropalaeontology, 27:103-110.

KARRER, F. 1866. Über das Auftreten von Foraminiferen in den alteren Schichten des Wiener Sandsteins. Sitzungsberichte der kaiserlichen Akademie der Wissenschaften, Mathematisch-naturwissenschaftliche Klasse, 52, (Jahrg 1865), Abt. 1, 492-497.
Kenn, J. P. 1977. Lebensspuren und Paläomilieu der Sieveringer Schichten (Oberkreide) des Wiener Waldes (Österreich). Mitteilungen der Gesellschaft der Geologischen Bergbaustudienten von Österreich, 24:11-45.

KsiaZkiewicZ, M. 1977. Trace fossils in the flysch of the Polish Carpathians. Palaeontologia Polonica, 36, 208 p.

Neagu, T. 1964. Duże otwornice aglutynujace z kampanu Karpat Rumuńskich (Large size agglutinated foraminifera from the Campanian of Rumanian Carpathians). Rocznik Polskiego Towarzystwa Geologicznego, 34:579-588.

NoTH, R. 1912. Die Foraminiferenfauna der roten Tone von Barwinek und Karmarnók. Beiträge zur Paläontologie und Geologie ÖsterreichUngarns und des Orients, 25:1-24, 1 pl.

OszCZYPKo, N. 1992. Late Cretaceous through Paleogene evolution of the Magura Basin. Geologica Carpathica, 43:333-338.

OsZCZYPKo, N., J. DudZIAK, AND E. MALATA. 1990. Stratygrafia osadów płaszczowiny magurskiej (kreda-paleogen) w Beskidzie Sadeckim, Karpaty zewnetrzne (Stratigraphy of the Cretaceous through Palaeogene deposits of the Magura Nappe in the Beskid Sadecki Range, Polish Outer Carpathians). Studia Geologica Polonica, 42:109-181.

OsZCZYPKo, N. AND N. PoREBSKI. 1985. Sixth Day, Stop 70, p. 120-123. In K. Birkenmajer (ed.), Main Geotraverse of the Polish Carpathians (Cracow-Zakopane). Guide to Excursion 2. Carpatho-Balkan Geological Association, $13^{\text {th }}$ Congress, Cracow Poland. Geological Institute, Warsaw.

OsZCZYPKO, N. AND N. PoREBSKI. 1986. Potok Życzanowski, p. 120-123. In K. Birkenmajer and D. Poprawa (eds.), Przewodnik 57 Zjazdu Polskiego Towarzystwa Geologicznego, Pieniński Pas Skałkowy, 18-20 września 1986 r. Kraków.

PličKa, M. AND V. THOMKA. 1990. Halimedaites carpaticus gen. n. sp. n., "body fossil" from the Carpathian flysch of Czechoslovakia. Západne Karpaty, séria Paleontológia, 14:125-132.

SeILACHER, A. 1959. Zur ökologischen Charakteristik von Flysch und Molasse. Eclogae Geologicae Helvetiae, 51(1958):1062-1078.

SCHRÖdER, C. J., F. S. Medioli, AND D. B. SCOTT. 1989. Fragile abyssal foraminifera (including new Komokiacea) from the Nares Abyssal Plain. Micropaleontology, 35:10-48.

SCHUBERT, R. J. 1902. Neue und interessante Foraminiferen aus dem südtiroler Altteriär. Beiträge zur Paläontologie und Geologie Österreich-Ungarns und des Orients, 14:9-26.

ŚwIDZIŃSKI, H. 1934. Uwagi o budowie Karpat fliszowych (Remarques sur la structure des Karpates flyscheuses). Biuletyn Państwowego Instytutu Geologicznego, 8:75-139.

Tendal, O. S. AND R. R. Hessler. 1977. An introduction to the biology and systematics of Komokiacea (Textulariina, Foraminiferida). Galathea Reports, 14:165-194.

UChman, A. 1998. Taxonomy and ethology of flysch trace fossils: a revision of the Marian Ksiazzikiewicz collection and studies of complementary material. Annales Societatis Geologorum Poloniae, 68:105-218.

UlRICH, E. O. 1904. Fossils and age of the Yakutat Formation. Description of the collections made chiefly near Kadiak, Alaska, p. 125-146. In B. K. Emerson, C. Palache, W. H. Dall, E. O. Ulrich, and F. H. Knowlton. Alaska. Vol. 4, Geology and Paleontology. Doubleday, Page \& Co., New York. [reprinted in 1910 as Smithsonian Institution Harriman Alaska Series, Vol. 4].

Unger, F. 1841. Chloris Protogaea. Beiträge zur Flora der Vorwelt. Wilhelm Engelmann, Leipzig, $110 \mathrm{p}$.

VIALOV, O. S. 1966. O krupnykh kremnistykh foraminiferakh Silicinifera iz Verkhnemelovogo flisha Karpat (Large siliceous foraminifer Silicinifera from the Upper Cretaceous flysch of the Carpathians). Paleontologichesky Sbornik, 3(2):27-36. Lviv.

ACCEPTED 14 July 2010 